\title{
兵庫県南部地震の被災建築物における柱梁部材の材質変化 に関する実験的研究

\author{
EXPERIMENTAL STUDY ON THE CHANGE OF PROPERTY OF BEAM AND \\ COLUMN OF THE STEEL STRUCTURE WHICH WAS \\ SUFFERED BY HYOUGOKEN-NANBU EARTHQUAKE
}

\author{
中込忠男*1, 青木博文*2, 杉本浩一*3, 大林郁 良*4 \\ Tadao NAKAGOMI, Hirohumi AOKI, Kouichi SUGIMOTO \\ and Ikurou OHBA YASI
}

\begin{abstract}
In Hyogoken-Nanbu earthquake which occurred in January, 1995, a lot of steel structures brittle fractured.It is necessary to make relation between the brittle fracture, the plastic strain record and the property change clear to prevent the occurrence of the brittle fracture.

In this study, it carried out the investigation of the damage situation about some steel structure which was suffered by Hyogoken-Nanbu earthquake. Also, it gathered test pieces from the steel structure and it carried out Charpy impact test, Vickers hardness test and tensile test.It made the situation of the property change clear as the result.Also, it made relation between the plastic strain record and the property change clear.
\end{abstract}

Keywords: HYOUGOKEN-NANBU EARTHQUAKE, plastic strain, brittle fracture, mechanical tests, changes of properties, 兵庫県南部地震、塑性歪、脆性破壊、材料試験、材質変化

1.はじめに

1995 年 1 月 17 日、淡路島北東約 $3 \mathrm{~km}$ 、深さ $20 \mathrm{~km}$ を震源と寸る、 兵庫県南部地震が発生した。マグニチュード7.2、震度は7在記録 し、神戸を中心に被害は多方に及び、建物・家屋の倒壊、火災の発 生、鉄道・道路の寸断、ライフラインの壊滅等により約 6,400 人の 死者出寸大惨事上なった。建築物の被害も一般住宅や RC 造を中 心に相当数に及び、鉄骨構造物も例外ではなく、研究の段階でその 発生が危惧されていた ${ }^{12.2)}$ 脆性破壊が発生したものが数多く見られ たこれまでの研究成果から、柱梁溶接接合部の変形能力を向上さ せるためには脆性破壊の発生を防止寸る必要があることがわかっ ている ${ }^{3) .49}$ 。脆性破壊の発生要因としては溶接接合部の勒性、梁端溶 接部のスカラップの存在とディテール 5, 6.7.7,8).99、裏当て金やエンド タブの組立溶接、バス間温度や入熱量なごの溶接条件 ${ }^{10) 、 ひ す ゙ み ~}$

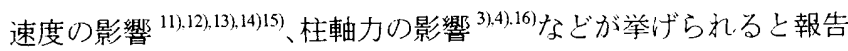
されている。これらの発生要因が複雑に絡み合って柱梁溶接接合部 の変形能力が決定される。これらの中で使用鋼材の材質という点に ついて考えると、塑性歪履歴を受けると鋼材の材質が劣化するのは 明らかであり、この点を考えた上で使用鋼材の材質の基準を考える
必要がある。

鉄骨建築物に用いられる鋼材の力学的性能や破壊䩚性について、 これまでにいくつかの研究がなされている 17)18),19)。青木・中込・ 知部らは、熱間矯正法による勒性劣化に関する研究を行なってい $z^{201.21)}$ 。藤本、青木、中込らは電炉広幅平鋼および電炉厚鋼板 （SM490A）を用いた柱・梁接合部に関寸る実験を行ない、その破 壊性状上素材特性の関係孝検討している 22,233,24),25)。乙の結果、使 用鋼材の $0^{\circ} \mathrm{C}$ 吸収エネルギーが70J以上であれば破壊しにくくなる 上報告している。ここで現在の規格に比心゙て非常に大きな值を示 す心は、破壊するまでに与えられる塑性歪によって鋼材の材質が 大きく劣化古るためと考えられる。したがって、塑性歪による鋼 材の材質変化状況を把握する必要がある。

中込・青木らは、単調引張載荷によって塑性歪を受けた鋼板の 各種材料試験を行い、塑性歪を受けた鋼材は処女材に比心゙てて勒性

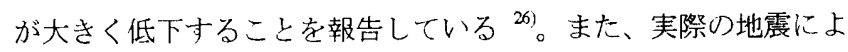
って受けると思われる、繰返し塑性歪による SM490A 鋼板の材質 劣化について実験的に険討し、近似式を用いて塑性歪上材質劣化 の関係を明らかにしている ${ }^{27)}$

\footnotetext{
*1 信州大学二工学部社会開発工学科教授・工博

*2 横浜国立大学工学部建設学科 教授・工博

*3 陎大林組 技術研究所

*4 信州大学工学部社会開発工学科 大学院生 (現, 旭化成工業株式会社・工修)
}

Prof., Dept. of Architecture and Civil Engineering, Faculty of Engineering, Shinshu Univ., Dr. Eng.

Prof., Dept. of Architecture, Faculty of Engineering, Yokohama National Univ., Dr. Eng.

Technical Research Institute, Obayashi Corporation

Graduated Student, Dept. of Architecture and Civil Engineering, Faculty of Engineering, Shinshu Univ. (Presently Asahi Chemica! Industry, M. Eng.) 
長谷川は兵庫県南部地震で被災した鉄骨建築物について弾塑性 応答解析を行い、破断状況上比較㭘討しながら実際にじのような 入力があったかなどを明らかにしている28!。また、青木・鈴木ら 统床スラブの影響索考慮し、地震办を受けた場合の梁端ひずみの 挙動堂数值解析により明らかにしている ${ }^{29}$

本研究では、長谷川および青木らが解析対象よした 5 階建て鉄骨 ラーメン構造建築物から素材試験片を採取し、材質の変化状況から 柱梁接合部がじのような履歴を受けて破壊に至ったのかを明らか に寸る。こうした実際の被災建築物に関して、その柱梁接合部の变 形状況や歪履歴、入力状況などを調心゙る研究は行われておらず、建 築鉄骨の耐震設計を考える上で大変興味深いこしと考えられる。

\section{2. 対象建築物の概要}

\section{1 建物概要}

以下に、建物概要をあげる。建物の形状寸法を、図 1 亿示守。柱 梁部材の断面性能表 $1 、 2$ 亿示吉。

\begin{tabular}{|c|c|}
\hline - 所在地 & 兵庫県神戸市中央区 \\
\hline ·階数 & 地上 5階建、地下なし \\
\hline ·高さ & $18.70 \mathrm{~m}$ (バラベット上端まで $)$ \\
\hline ·延心床面積 & $1,624 \mathrm{~m}^{2}$ \\
\hline ·構造種類 & 鉄骨造 \\
\hline ·構造形式 & 2 方向ラーメン構造 \\
\hline ·主要構造部使用材料. & 梁-H 形鋼、柱一角形鋼管 (SS41) \\
\hline ·基礎形式 & 杭基礎 $450 \phi \cdot \mathrm{B}$ 種 $\mathrm{AC}$ 杭 \\
\hline 梁接合部 & スカラッブ $(r=40)$ 学有寸工場型溶 \\
\hline & 通しダイアフラム形式 \\
\hline
\end{tabular}

建物は地上 5 階建てで、南北方向に 4 スバン、東西方向に 2 ス パンの 2 方向ラーメン構造で、事務所ビルとして使用されてていた。 主要構造部使用鋼材はSS41 で、柱梁接合部は梁スカラッブを有す るブラケットタイプの工場溶接である。

\section{2 被害状況}

建物の被害状況は、H 形鋼を用いた梁について注、南北方向のス カラップ近傍の下フランジで破壊が多くみられ、2、3 階床梁はほ 上んよ゙す心゙て、4階床梁は所々で脆性破壊もしくは延性破壞を起こ していた。東西方向の梁は、2、3 階床梁で多少の塑性変形が見ら れた程度で、汪上んど被害は見られない。角形鋼管の柱は、3階柱 頭部で所々局部座屈が見られただけであった。南北方向ラーメンに 执ける被害状況を確認できた範囲で図 2 に示寸。

脆性破壊はす心゙て梁スカラッブ端部を起点として発生したと思 われる。スカラッブ端部と裏当て金の組立て溶接止端部が重なるよ うの存在しており、過去に行われた実大実験からも破壊しや子い条 件であったことがうかがえる。この事からも、スカラッブ端部上重 なるような位置では裏当て金の組立て溶接劣行なうぶきではない ここが再確認された。図 3 に破断位置の詳細を示寸。図中心距雄は 素材試験片採取位置を示示ものである。しかし、脆性破壊した梁に おいても、はっきり上降伏線が入っているのが確認でき、十分な塑

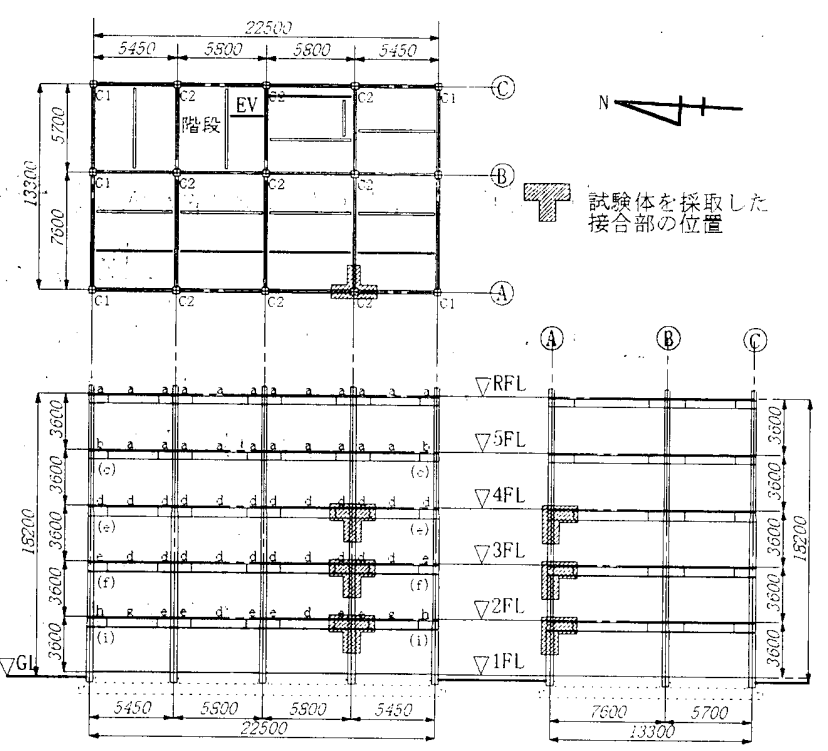

図 1 被災建築物の形状

表 1 . 梁の断面形状

\begin{tabular}{|c|c|c|c|c|c|}
\hline 記 & & & & & \\
\hline$\frac{0}{5}$ & & & 階 & $\mathrm{Cl}$ & $\mathrm{C} 2$ \\
\hline & & & 5 & $\square-350 \times 12$ & $\square-350 \times 12$ \\
\hline a & 496 & $\because$ & 4 & $\square .350 \times 12$ & $\square-350 \times 12$ \\
\hline $\mathrm{b}$ & $\mathrm{H}-500 \times 2$ & C & 3 & $\square-400 \times 12$ & $\square-400 \times 12$ \\
\hline c: & $\mathrm{BH}-500 \times$ & 用 & 2 & $\square-400 \times 16$ & $\square-400 \times 16$ \\
\hline d & $\mathrm{H}-596 \times 19$ & & 1 & $\square-400 \times 19$ & $\square-450 \times 16$ \\
\hline $\mathrm{e}$ & $\mathrm{H}-600 \times 20$ & & 5 & $\square-350 \times 12$ & $\square-350 \times 12$ \\
\hline $\mathrm{f}$ & $\mathrm{BH}-600 \times 250 \sim 200 \times 12 \times 16$ & & 4 & $\square .350 \times 12$ & $\square .400 \times 12$ \\
\hline $\mathrm{g}$ & $\mathrm{H}-606 \times 201 \times 12 \times 20$ & 通 & 3 & $\square-400 \times 12$ & $\square-400 \times 16$ \\
\hline $\mathrm{h}$ & BH $-600 \times 250 \sim 200 \times 12 \times 19$ & 5 & 2 & {$[-400 \times 16$} & $\square-400 \times 19$ \\
\hline$i$ & BH- $600 \times 275 \sim 200 \times 12 \times 19$ & & 1 & $\square-450 \times 19$ & $\square-450 \times 22$ \\
\hline
\end{tabular}

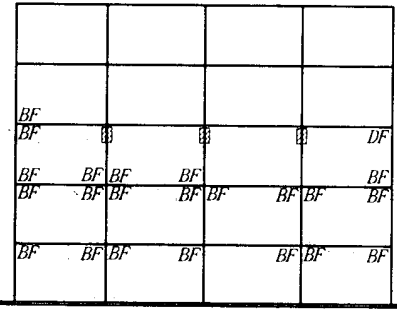

A通り

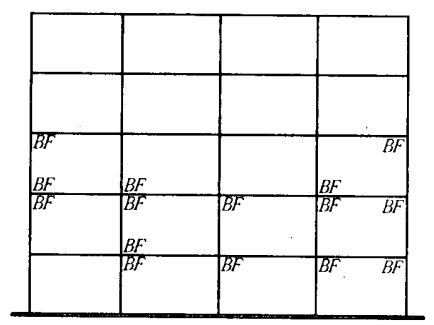

C通り

\section{図 2 被害状況}

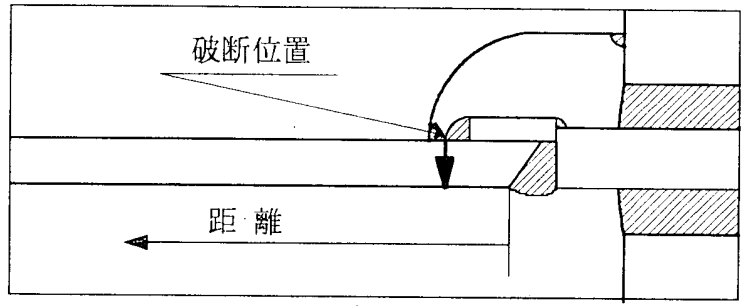

図 3 破断位置詳細 
表 3 試験片採取部材の化学成分

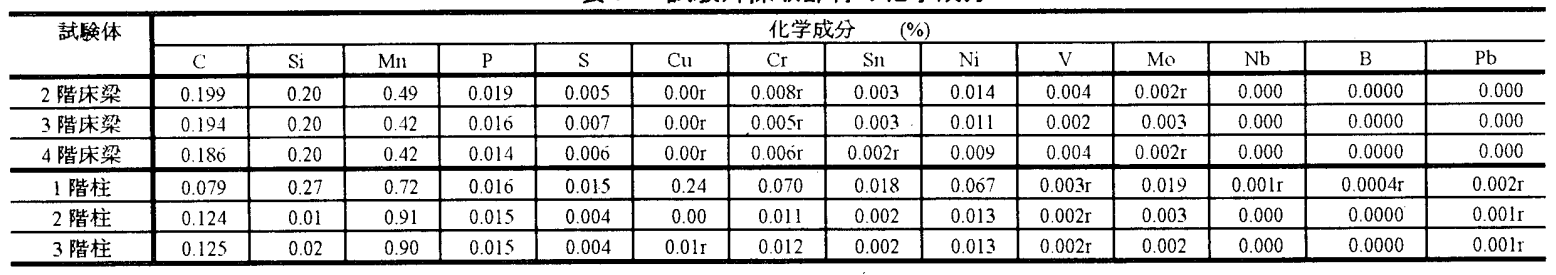

性変形の後に脆性破壊したものと思われる。これは、崩壊しない程 度に部材を破断させることで建物全体の崩壊を防ぐよいう、現行の 而震設計法の基本方針を十分に満足した建物であったと言える。

建物は、南北方向に細長い $2 \times 4$ スパンの構造物であるため、2 スバンの東西方向よりも 4 スバンの南北方向の方が剛性が高い性 ずである。しかし、調査によると南北方向の梁に大きな被害が生じ ているため、建物は南北方向の外力を受けた上予想される。 他の鉄骨造建築物に扔いてもこのような脆性的な破断が数多く見 られたが、施工不良なごを原因上したものを除けば、RC 造や木造 住宅などのように崩壊や倒壊して人身に被害が出るようなことは 見られなかったことから鉄骨構造物の耐震性の高さがうかがえる。

\section{3. 試験概要}

\section{1 試験片の採取}

被害の状況からみて大、大きな変形を受忛たと考方られる2 階から 4 階床梁を含む 3 箇所の柱梁接合部を、柱・梁ともに接合部から約 1 m離れた位置まで採取した。図 1 に取り出した柱梁接合部及び近傍 の柱梁部材の位置を示寸。

取り出した柱梁接合部近傍の柱梁部材から、ビッカース硬さ試 験片、シャルピー衝揧試験片、引張り試験片をそれぞれ歪を受けて いない上考えられる位置まで連続的に L 方向に採取した。建物は 南北方向に入力があったと思われるので、南北方向ラーメンについ て検討妾行なう。したがって、試験片は南北方向の H 形鋼梁フラ ンジ及びの角形鋼管柱の南北平行面から採取した。2、4 階床梁は、 柱に対して北側の梁から、3 階床梁は北側の梁で座屈が激く試験片 の採取が困難であるこよから、南側の梁から採取した。

\section{2 使用鎡材の化学成分}

材料試験片を採取した部材の化学成分を調查した結果を表 3 に 示す。C などの成分完見る上、1階柱だけが電炉鋼で、他の部材 汢全て高师材である。考えられる。また、 $\mathrm{Si}$ 老見る上2、3 階柱の 含有率が $0.01 \%$ 上小さい。

\section{4. 試験結果}

\section{1 引張試験結果}

引張試験片の形状寸法学図 4 亿示寸。載荷は、 $250 \mathrm{kN}$ 万能試験機 を用い変位速度 $1 \mathrm{~mm} / \mathrm{min}$ の変位制御上た。引張り試験結果の概要 を表 4 に示寺。ここでの距離法、図 3 に示寸上うに溶接止端部を 原点上した試験片中央までの距離である。

梁に扔いては、梁端部近傍で降伏応力、最大応力の上昇、一様伸 びの減少等の力学的性能の変化が顕著に見られるが、柱では変化は

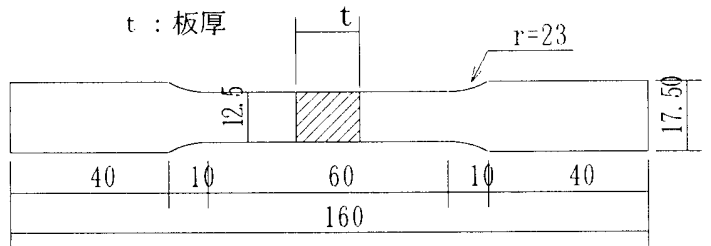

図 4 引張試験片形状 表 4 引張試験結果の概要

\begin{tabular}{|c|c|c|c|c|c|c|c|}
\hline & $\begin{array}{l}\text { 距離 } \\
(\mathrm{mm})\end{array}$ & $\begin{array}{c}\sigma_{\mathrm{y}} \\
\left(\mathrm{N} / \mathrm{mm}^{2}\right)\end{array}$ & $\begin{array}{c}\sigma_{11} \\
\left(\mathrm{~N} / \mathrm{mm}^{2}\right)\end{array}$ & $\frac{\sigma_{\mathrm{y}}}{\sigma_{\mathrm{u}}}$ & $\begin{array}{l}\varepsilon \mathrm{u} \\
(\%)\end{array}$ & $\begin{array}{l}\varepsilon f \\
(\%)\end{array}$ & $\begin{array}{c}\phi \\
(\%)\end{array}$ \\
\hline $\begin{array}{l}\text { 2階床梁 } \\
\text { 上フランジ }\end{array}$ & $\begin{array}{r}99.5 \\
800 \\
\end{array}$ & $\begin{array}{l}375.0 \\
310.7\end{array}$ & $\begin{array}{l}493.4 \\
380.6 \\
\end{array}$ & $\begin{array}{l}0.76 \\
0.65 \\
\end{array}$ & $\begin{array}{l}13.9 \\
23.5 \\
\end{array}$ & $\begin{array}{l}32 \\
42 \\
\end{array}$ & $\begin{array}{l}59 \\
61 \\
\end{array}$ \\
\hline $\begin{array}{l}\text { 2階床梁 } \\
\text { 下フランジ }\end{array}$ & $\begin{array}{l}99.5 \\
800\end{array}$ & $\begin{array}{l}328.6 \\
293.6 \\
\end{array}$ & $\begin{array}{l}501.2 \\
471.6 \\
\end{array}$ & $\begin{array}{l}0.66 \\
0.62 \\
\end{array}$ & $\begin{array}{l}10.1 \\
23.6 \\
\end{array}$ & $\begin{array}{l}27 \\
41 \\
\end{array}$ & $\begin{array}{l}28 \\
61 \\
\end{array}$ \\
\hline $\begin{array}{l}\text { 3階床梁 } \\
\text { 上フランジ }\end{array}$ & $\begin{array}{r}99.5 \\
800 \\
\end{array}$ & $\begin{array}{l}349.3 \\
313.2\end{array}$ & $\begin{array}{l}490.6 \\
470.1 \\
\end{array}$ & $\begin{array}{l}0.71 \\
0.67 \\
\end{array}$ & $\begin{array}{l}12.3 \\
24.2 \\
\end{array}$ & $\begin{array}{l}29 \\
40\end{array}$ & $\begin{array}{l}61 \\
61 \\
\end{array}$ \\
\hline $\begin{array}{l}\text { 3階休梁 } \\
\text { 下フブンジ }\end{array}$ & $\begin{array}{l}99.5 \\
800\end{array}$ & $\begin{array}{l}406.4 \\
297.5\end{array}$ & $\begin{array}{l}498.1 \\
456.4\end{array}$ & $\begin{array}{l}0.82 \\
0.65\end{array}$ & $\begin{array}{l}10.9 \\
24.6\end{array}$ & $\begin{array}{l}28 \\
41\end{array}$ & $\begin{array}{l}59 \\
62\end{array}$ \\
\hline $\begin{array}{l}\text { 4階朱梁 } \\
\text { 上フランジ }\end{array}$ & $\begin{array}{l}99.5 \\
800\end{array}$ & $\begin{array}{l}301.8 \\
300.4\end{array}$ & $\begin{array}{l}462.8 \\
462.6\end{array}$ & $\begin{array}{l}0.65 \\
0.65\end{array}$ & $\begin{array}{l}21.7 \\
23.3\end{array}$ & $\begin{array}{l}41 \\
39\end{array}$ & $\begin{array}{l}61 \\
60\end{array}$ \\
\hline $\begin{array}{l}\text { 4階休梁 } \\
\text { 下フランジ }\end{array}$ & $\begin{array}{r}99.5 \\
800\end{array}$ & $\begin{array}{l}317.9 \\
291.8\end{array}$ & $\begin{array}{l}476.1 \\
461.4\end{array}$ & $\begin{array}{l}0.67 \\
0.63\end{array}$ & $\begin{array}{l}13.2 \\
23.8\end{array}$ & $\begin{array}{l}29 \\
39 \\
\end{array}$ & $\begin{array}{l}60 \\
61 \\
\end{array}$ \\
\hline $\begin{array}{c}1 \text { 階柱頭 } \\
\text { 北側面 }\end{array}$ & $\begin{array}{l}103.5 \\
888.5 \\
\end{array}$ & $\begin{array}{l}309.6 \\
309.4 \\
\end{array}$ & $\begin{array}{l}438.5 \\
439.8 \\
\end{array}$ & $\begin{array}{l}0.71 \\
0.70 \\
\end{array}$ & $\begin{array}{l}24.7 \\
23.6 \\
\end{array}$ & $\begin{array}{l}46 \\
47\end{array}$ & $\begin{array}{l}68 \\
68\end{array}$ \\
\hline $\begin{array}{c}1 \text { 階柱頭 } \\
\text { 南側面 }\end{array}$ & $\begin{array}{l}103.5 \\
888.5 \\
\end{array}$ & $\begin{array}{l}301.7 \\
310.4 \\
\end{array}$ & $\begin{array}{l}432.2 \\
442.9 \\
\end{array}$ & $\begin{array}{l}0.70 \\
0.70 \\
\end{array}$ & $\begin{array}{l}24.5 \\
24.0 \\
\end{array}$ & $\begin{array}{l}45 \\
46 \\
\end{array}$ & $\begin{array}{l}68 \\
69 \\
\end{array}$ \\
\hline $\begin{array}{c}2 \text { 階柱頭 } \\
\text { 北側面 }\end{array}$ & $\begin{array}{l}103.5 \\
888.5\end{array}$ & $\begin{array}{l}379.6 \\
351.8 \\
\end{array}$ & $\begin{array}{l}438.8 \\
434.7 \\
\end{array}$ & $\begin{array}{l}0.87 \\
0.81\end{array}$ & $\begin{array}{l}21.0 \\
19.8\end{array}$ & $\begin{array}{l}44 \\
44\end{array}$ & $\begin{array}{l}71 \\
70\end{array}$ \\
\hline $\begin{array}{c}2 \text { 階柱頭 } \\
\text { 南側面 }\end{array}$ & $\begin{array}{l}103.5 \\
888.5\end{array}$ & $\begin{array}{l}357.1 \\
363.6 \\
\end{array}$ & $\begin{array}{l}437.9 \\
430.4 \\
\end{array}$ & $\begin{array}{l}0.82 \\
0.84\end{array}$ & $\begin{array}{l}16.6 \\
17.5\end{array}$ & $\begin{array}{l}40 \\
40\end{array}$ & $\begin{array}{l}71 \\
70\end{array}$ \\
\hline $\begin{array}{c}\text { 3階柱頭 } \\
\text { 北側面 }\end{array}$ & $\begin{array}{l}103.5 \\
888.5 \\
\end{array}$ & $\begin{array}{r}(229.3) \\
347.1 \\
\end{array}$ & $\begin{array}{r}(437.1) \\
421.8 \\
\end{array}$ & $\begin{array}{r}(0.52) \\
0.82 \\
\end{array}$ & $\begin{array}{r}(21.7) \\
19.7 \\
\end{array}$ & $\begin{array}{r}(41) \\
44 \\
\end{array}$ & $\begin{array}{r}(70) \\
71 \\
\end{array}$ \\
\hline $\begin{array}{c}3 \text { 階柱頭 } \\
\text { 南側面 }\end{array}$ & $\begin{array}{l}103.5 \\
888.5\end{array}$ & $\begin{array}{r}(236.4) \\
320.3 \\
\end{array}$ & $\begin{array}{r}(426.3) \\
425 .\end{array}$ & $\begin{array}{r}(0.55) \\
0.75 \\
\end{array}$ & $\begin{array}{r}(19.7) \\
22.7\end{array}$ & $\begin{array}{r}(39) \\
44\end{array}$ & $\begin{array}{r}(70) \\
71\end{array}$ \\
\hline
\end{tabular}

ほ上んよ゙見られなかった。接合部からの距離上降伏応力、引張強さ、 一様伸ずの関係省図 5、6に示寺。

2 階床梁上下フランジと 3 階床梁上フランジでは、材質の変化が $300 \mathrm{~mm}$ 程度であるるにに対して、3 階床梁下フランジでは $450 \mathrm{~mm}$ 以 上よなっており、塑性域が最も広くなっている。4 階床梁上フラン ジでは梁端部に最も近い位置でのみ、材質の变化が見られる。3 階 床梁下フランジで最も材質の変化が大きく、降伏応力は約 $70 \mathrm{~N} / \mathrm{mm}^{2}$ 、 引張强さは約 $40 \mathrm{~N} / \mathrm{mm}^{2}$ の上昇、一様伸びは約 $14 \%$ の低下が見られ， る。一様伸びの低下量は、そ心鋼材が受けたスケルトン歪に対応寸 るよ考えられるため、2,3 階梁下フランジの梁端部では地震による 繰返し力によって 14\%以上の非常に大きなスクルトン歪を受けた こよが推測できる。

\section{2 ビッカース硬さ試験結果}

硬さ試験片は2,3,4階南北床梁の上下フランジ及び $1,2,3$ 階箱型断 面柱の南北平行面において、柱梁接合部から塑性歪を受けていない と考えられる位置まで、梁幅中央付近老切れ、目のないように連続的 


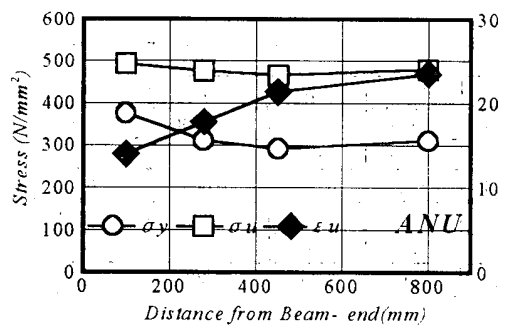

a) 2 階床梁上フランジ

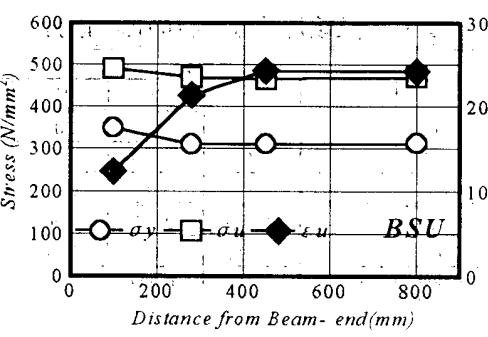

b) 3 階床梁上フランシ

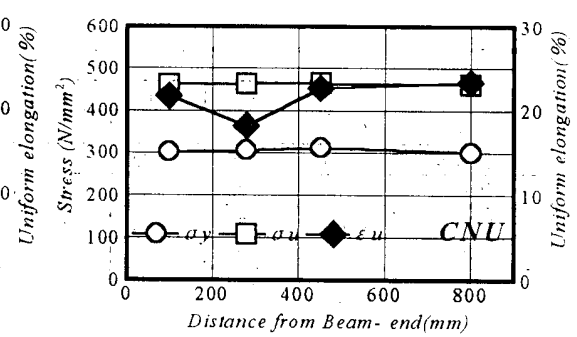

c) 4 階床梁上フランジ

図 5 降伏応力・引張強さ・様伸びと梁端接合部からの距離（上フランジ）

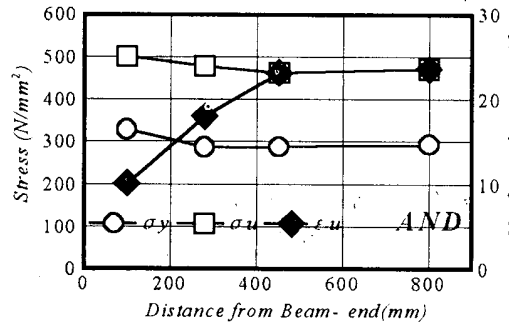

a) 2 階休梁下フランジ

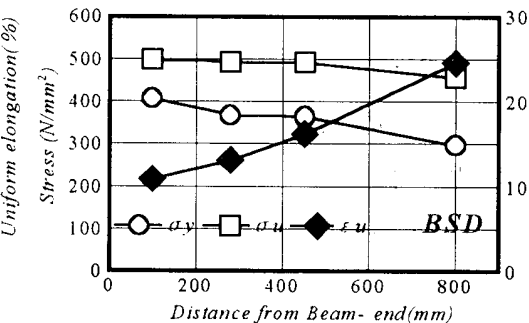

b) 3 階床梁下フランジ

图 6 降伏応力・引張強さ・一様伸びと梁端接合部からの距離の関係（下フランジ）

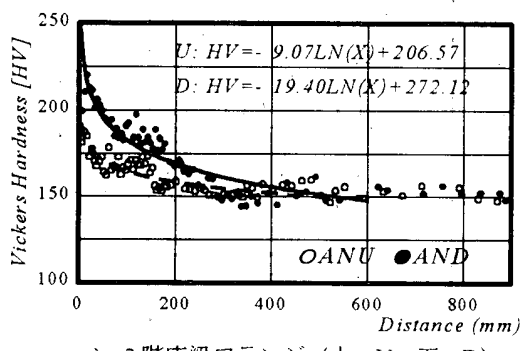

a) 2 階休梁フランジ (上：U、下：D）

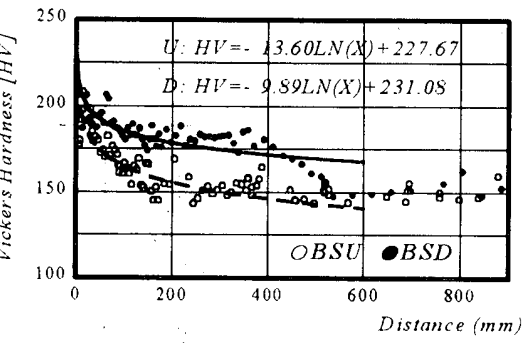

b) 3階代梁フランジ(上：U、下：D)

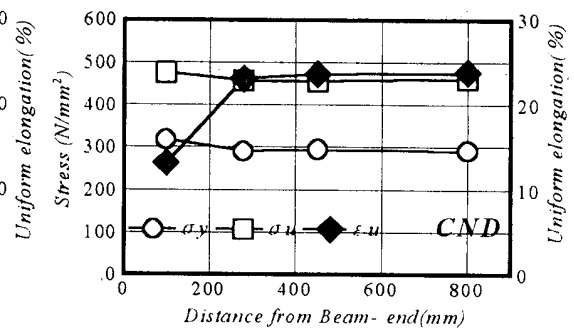

c) 4 階床梁下フランジ

图 7 梁フランジのビッカース硬さと梁端接合部からの距離の関係

に採取した。打点は、LZ断面に試験荷重 $1 \mathrm{kgf}$ で行なった。

ビッカース硬さ試験結果も引張試験上同様、柱は材質の変化がほ とんど見られなかった。梁端部からの距離とビッカース硬さの関保

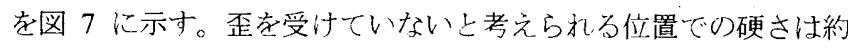
$150 \mathrm{HV}$ であり、柱梁接合部に近付くにつれて硬化が進んでいる。 最も硬さが増加したのは、脆性破壊が見られた 2,3 階床梁下フラン ジで、梁端部付近で硬さが $200 \mathrm{HV}$ 以上の值を示し、約 $50 \mathrm{HV}$ の上 昇が見られた。硬さが上昇している範囲は、2 階床梁が梁端部から 約 $300 \mathrm{~mm}$ の間であるのに対し 3 階床梁恃約 $500 \mathrm{~mm}$ よなっている。 引張試験結果、ビッカース硬さ試験結果よもに2,3階床梁フラン ジで性材質の変化が顕著に見られ、大きな入力による十分な塑性変 形の後に脆性破壊したもの上考えられる。

\section{3 シャルビー衝撃試験結果}

$2,3,4$ 階南北床梁の上下フランジ及び $1,2,3$ 階箱型断面柱の南北平 行面に扔いて、柱梁接合部加塑性歪を受けていない上考えられる 位置まで、梁フランジは 8 箇所、柱平行部は 9 箇所から試験片孛 採取した。試験片は MS4 号 Vノッチ試験片を用いた。試験片はフ ランジ表面側にノッチを取り、フランジ表面に近い位置から採取し た。遷移曲線恃式 (3.1)、(3.2)上り求めた。

$v E=v E$ shelf $\{1+\tanh \alpha(T-$ Tre $)\} / 2$

$B=50\{1-\tanh \beta(T-\operatorname{Tr} s)\}$

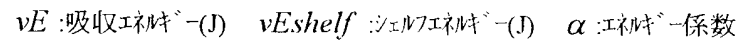
Tre :吸収䘜时”一遷移温度 $\left({ }^{\circ} \mathrm{C}\right) \quad B$ : 脆性破面率

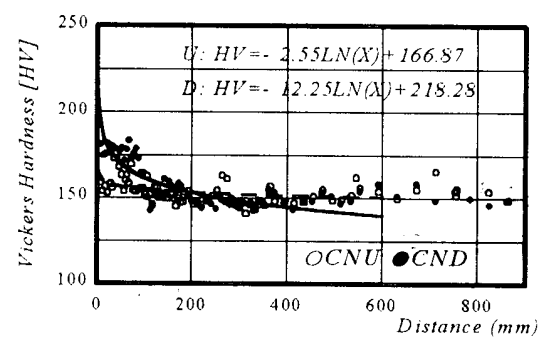

c) 4 階床梁フランジ (上：U、下：D)

表 5 シャルビー衝擊試験結果の概要

\begin{tabular}{|c|c|c|c|c|c|c|}
\hline & $\begin{array}{l}\text { 距離 } \\
\text { (Inu) }\end{array}$ & $\begin{array}{l}\text { vEshelf } \\
\text { (J) }\end{array}$ & $\begin{array}{c}\mathrm{vEO} \\
(\mathrm{J}) \\
\end{array}$ & $\begin{array}{l}\text { vTre } \\
\text { (C) }\end{array}$ & $\begin{array}{l}\text { vTrs } \\
\text { (C) }\end{array}$ & $\begin{array}{l}\mathrm{vBo} \\
(\%)\end{array}$ \\
\hline $\begin{array}{l}2 \text { 階床梁 } \\
\text { 上フランジ }\end{array}$ & $\begin{array}{l}39.5 \\
800\end{array}$ & $\begin{array}{l}157.5 \\
176.1\end{array}$ & $\begin{array}{r}10.5 \\
106.3\end{array}$ & $\begin{array}{l}29.6 \\
-5.0\end{array}$ & $\begin{array}{r}31.9 \\
-4.4\end{array}$ & $\begin{array}{r}1000 \\
36.6\end{array}$ \\
\hline $\begin{array}{l}\text { 2階床梁 } \\
\text { 下フランジ }\end{array}$ & $\begin{array}{r}39.5 \\
800 \\
\end{array}$ & $\begin{array}{l}179.4 \\
187.8\end{array}$ & $\begin{array}{l}48.2 \\
94.8\end{array}$ & $\begin{array}{l}37.6 \\
-0.4\end{array}$ & $\begin{array}{r}38.3 \\
1.5 \\
\end{array}$ & $\begin{array}{l}83.2 \\
52.3\end{array}$ \\
\hline $\begin{array}{l}\text { 3階床梁 } \\
\text { 上フランン゙ }\end{array}$ & $\begin{array}{l}39.5 \\
800\end{array}$ & $\begin{array}{l}155.6 \\
164.2\end{array}$ & $\begin{array}{r}44.0 \\
120.7\end{array}$ & $\begin{array}{l}21.1 \\
-8.3\end{array}$ & $\begin{array}{l}23.7 \\
-4.1\end{array}$ & $\begin{array}{l}79.2 \\
35.7\end{array}$ \\
\hline $\begin{array}{l}\text { 3階床梁 } \\
\text { 下汸シ }\end{array}$ & $\begin{array}{l}39.5 \\
800\end{array}$ & $\begin{array}{l}146.9 \\
167.9\end{array}$ & $\begin{array}{r}18.4 \\
125.7\end{array}$ & $\begin{array}{r}40.5 \\
-11.2\end{array}$ & $\begin{array}{l}46.5 \\
-8.2\end{array}$ & $\begin{array}{l}95.4 \\
26.0\end{array}$ \\
\hline $\begin{array}{c}4 \text { 階床梁 } \\
\text { 上7湔 }\end{array}$ & $\begin{array}{l}39.5 \\
800 \\
\end{array}$ & $\begin{array}{l}156.4 \\
164.4\end{array}$ & $\begin{array}{l}111.4 \\
1210\end{array}$ & $\begin{array}{l}-12.3 \\
-15.1\end{array}$ & $\begin{array}{l}-6.1 \\
-8.3\end{array}$ & $\begin{array}{l}41.1 \\
35.8\end{array}$ \\
\hline $\begin{array}{l}4 \text { 4階来梁 } \\
\text { 下フランジ }\end{array}$ & $\begin{array}{r}39.5 \\
800 \\
\end{array}$ & $\begin{array}{l}60.7 \\
166.7 \\
\end{array}$ & $\begin{array}{r}63.2 \\
123.0 \\
\end{array}$ & $\begin{array}{r}10.9 \\
-14.5\end{array}$ & $\begin{array}{r}14.7 \\
-11.0 \\
\end{array}$ & $\begin{array}{l}69.6 \\
19.8\end{array}$ \\
\hline $\begin{array}{l}1 \text { 階柱頭 } \\
\text { 北側面 }\end{array}$ & $\begin{array}{r}43.5 \\
888.5 \\
\end{array}$ & $\begin{array}{l}220.9 \\
218.9 \\
\end{array}$ & $\begin{array}{l}202.5 \\
211.6\end{array}$ & $\begin{array}{l}-38.7 \\
-48.5\end{array}$ & $\begin{array}{r}-35.9 \\
-43.9 \\
\end{array}$ & $\begin{array}{l}5.2 \\
3.4 \\
\end{array}$ \\
\hline $\begin{array}{l}1 \text { 階柱頭 } \\
\text { 南側面 }\end{array}$ & $\begin{array}{r}43.5 \\
888.5 \\
\end{array}$ & $\begin{array}{l}229.2 \\
245.6 \\
\end{array}$ & $\begin{array}{l}223.7 \\
226.1\end{array}$ & $\begin{array}{r}-43.0 \\
-39.1\end{array}$ & $\begin{array}{l}-41.6 \\
-39.0\end{array}$ & $\begin{array}{l}0.2 \\
1.0\end{array}$ \\
\hline $\begin{array}{c}2 \text { 階柱頭 } \\
\text { 北側面 }\end{array}$ & $\begin{array}{r}43.5 \\
888.5 \\
\end{array}$ & $\begin{array}{l}297.9 \\
2900\end{array}$ & $\begin{array}{l}266.8 \\
289.0\end{array}$ & $\begin{array}{l}-13.6 \\
-25.8\end{array}$ & $\begin{array}{l}-15.4 \\
-31.0\end{array}$ & $\begin{array}{l}8.1 \\
0.0\end{array}$ \\
\hline $\begin{array}{c}2 \text { 階柱頭 } \\
\text { 南側面 }\end{array}$ & $\begin{array}{r}43.5 \\
888.5 \\
\end{array}$ & $\begin{array}{l}288.8 \\
295.5\end{array}$ & $\begin{array}{l}259.9 \\
257.5\end{array}$ & $\begin{array}{r}-15.8 \\
-8.8\end{array}$ & $\begin{array}{l}-16.6 \\
-10.8\end{array}$ & $\begin{array}{l}6.8 \\
8.8\end{array}$ \\
\hline $\begin{array}{c}3 \text { 階柱頭 } \\
\text { 北側面 }\end{array}$ & $\begin{array}{r}43.5 \\
888.5 \\
\end{array}$ & $\begin{array}{l}2890 \\
3009 \\
\end{array}$ & $\begin{array}{l}288.9 \\
2800 \\
\end{array}$ & $\begin{array}{l}-26.4 \\
-28.5 \\
\end{array}$ & $\begin{array}{l}-31.0 \\
-36,0\end{array}$ & $\begin{array}{l}0.0 \\
0.4\end{array}$ \\
\hline $\begin{array}{l}\text { 3階柱頭 } \\
\text { 南側面 }\end{array}$ & $\begin{array}{r}43.5 \\
888.5 \\
\end{array}$ & $\begin{array}{l}286.1 \\
296.3\end{array}$ & $\begin{array}{l}262.1 \\
270.6\end{array}$ & $\begin{array}{l}-15.2 \\
-15.0\end{array}$ & $\begin{array}{l}-16.8 \\
-17.4\end{array}$ & $\begin{array}{l}6.6 \\
6.1\end{array}$ \\
\hline
\end{tabular}

シャルピー衝撃試験結果の一覧を表 5 に示寸。表中の距離は梁端 部からノッチ位置专でのものと寸る。ざての部材で塑性歪花受け ていない上考えられる位置の $0^{\circ} \mathrm{C}$ 吸収エネルギーが $90 \mathrm{~J}$ 以上上なっ て扔り、十分な勒性を示していると考えられる。しかし、脆性破壊 


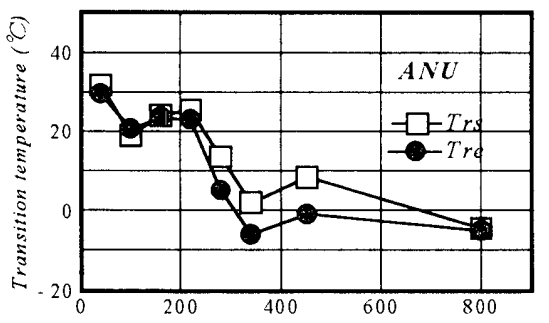

Distance from Beam-end $(\mathrm{mm})$

a) 2 階休梁上フランシ

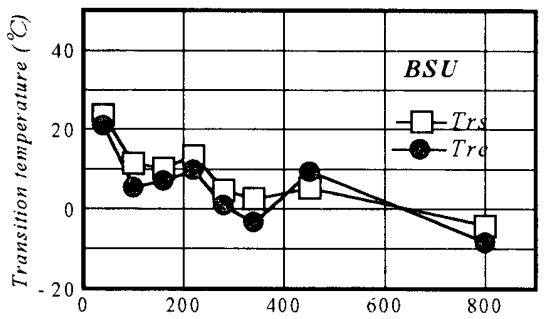

Distance from Beam-end ( $\mathrm{mm}$ )

b) 3 階沫梁上フランシ

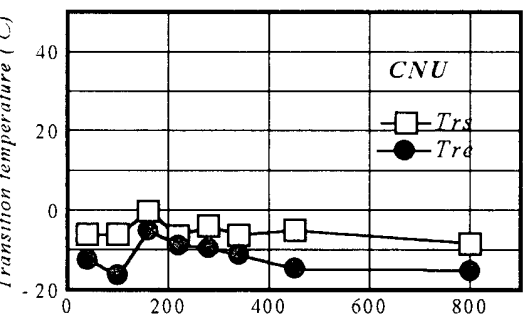

Distance from Beam-end ( $\mathrm{mm}$ ) c) 4 階床梁上フランジ

図 8 エネルギ一遷移温度・破面遷移温度と梁端接合部からの距離の関係（上フランジ）

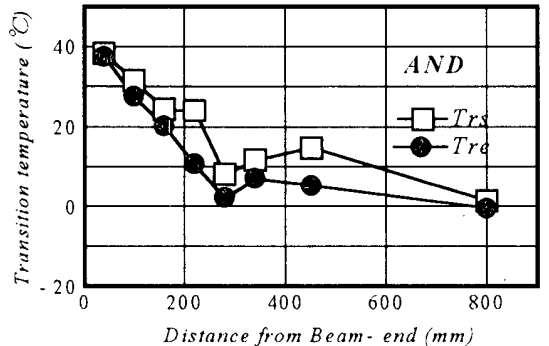

a) 2 階床梁下フランジ

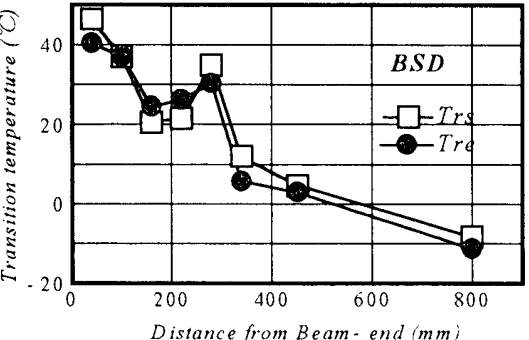

b) 3 階床梁下フランジ

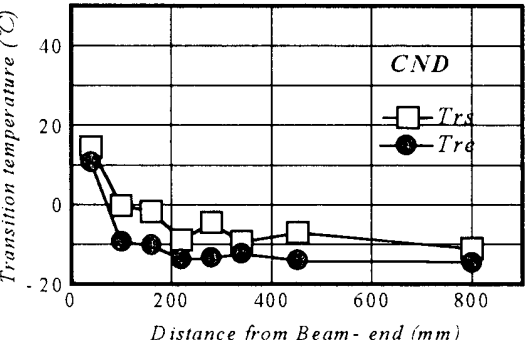

c) 4 階床梁下フランジ

図 9 エネルギー遷移温度・破面遷移温度と梁端接合部からの距離の関係（下フランジ）

が見られた 2,3 階床梁フランジの遷移温度が、柱や 4 階床梁に比バ て低い勒性を示している。この事が脆性破壊を起こした要因の一つ 上考えられる。また、梁フランジにおいて、柱梁接合部に近づくに つれて勒性の劣化が顕著に見られる。柱は、1,2,3 階上も勒性の劣 化がほ上んど見られない。接合部からの距離上エネルギー遷移温度、 脆性破面遷移温度の関係を図 $8 、 9$ に示寸。

2,3 階床梁フランジでは、塑性歪を受けていない上考えられる位 置に比バて梁端部近傍では遷移温度が 30〜 50 $\mathrm{C}$ 上昇しており、梁 端部から $400 \mathrm{~mm}$ 程度までの間で遷移温度の上昇が顕著に見られる。 このことから、十分な塑性変形の後に脆性破壊したもの上考えられ、 建物全体の崩壊を避けるようなエネルギー吸収能力を持たせる上 いう、現行の耐震設計方針を十分に満足したものと思加る。3 階 梁フランジでは、遷移温度の上昇は梁端部から $100 \mathrm{~mm}$ 程度であり、 破断した梁に比心変化量も変化した領域も小さく、大きな塑性歪は 受けていない上考えられる。

梁上フランジよ下フランジを比較寸る上、下フランジのほうが勒 性の劣化が著しい。こ礼梳、上フランジが床スラブによって拘束さ れてるこ上が原因上考えられ、2,3 階の上フランジが破断しなかっ たのもこれが原因であるう。

\section{5. 塑性歪による鋼材の硬化 \\ 5.1 試験概要}

これまでに、引張り試験、硬さ試験、シャルピー衝撃試験を行な いそれぞれの部材の材質の変化状況を把握するこ上はできたが、地 震によってどのような久力や歪受けたのかは浮りっりしていな い。硬さ分布をも上にして歪履歷の状况を推定するために塑性歪を 受けた鋼材の硬さの変化状況を調査し、塑性歪上硬さの関係を導き、 部材が受汁た歪履歴を推定する。

梁フランジの歪を受けていないし考えられる位置から採取した 引張り試験片 3 体孝用いて、引張り試験によって塑性歪を与える。

\begin{tabular}{|c|c|c|c|c|c|}
\hline \multicolumn{2}{|c|}{ NO.1 } & \multicolumn{2}{|c|}{ No.2 } & \multicolumn{2}{|c|}{ NO.3 } \\
\hline 予歪(\%) & $\mathrm{HV}$ & 予歪(\%) & $\mathrm{HV}$ & 予昰 $(\%)$ & $\mathrm{HV}$ \\
\hline 0 & 147.6 & 0 & 148.8 & 0 & 145.7 \\
\hline 1.22 & 148.3 & 1.27 & 149.6 & 1.55 & 150.4 \\
\hline 2.44 & 158.0 & 2.21 & 1609 & 2.56 & 147.7 \\
\hline 3.33 & 164.8 & 3.14 & 164.8 & 3.41 & 153.3 \\
\hline 4.36 & 174.0 & 4.04 & 175.0 & 4.43 & 162.8 \\
\hline 5.42 & 176.4 & 5.10 & 173.9 & 5.40 & 166.0 \\
\hline 6.39 & 179.5 & 5.59 & 181.4 & 6.17 & 172.7 \\
\hline 7.36 & 188.5 & 6.74 & 182.9 & 7.15 & 174.9 \\
\hline 8.33 & 182.9 & 7.79 & 185.5 & 8.11 & 175.7 \\
\hline 9.43 & 194.3 & 8.80 & 179.4 & 9.08 & 176.2 \\
\hline 1048 & 197.7 & 9.81 & 177.2 & 9.98 & 177.9 \\
\hline 11.51 & 199.9 & 10.80 & 186.6 & 10.89 & 179.5 \\
\hline 12.53 & 197.7 & 11.78 & 190.2 & 11.75 & 185.1 \\
\hline 13.54 & 196.1 & 12.82 & 192.0 & 12.22 & 180.1 \\
\hline 14.53 & 197.0 & 13.74 & 200.7 & 12.24 & 195.8 \\
\hline 15.47 & 204.9 & 14.71 & 191.8 & - & - \\
\hline 15.91 & 199.1 & - & - & - & - \\
\hline
\end{tabular}

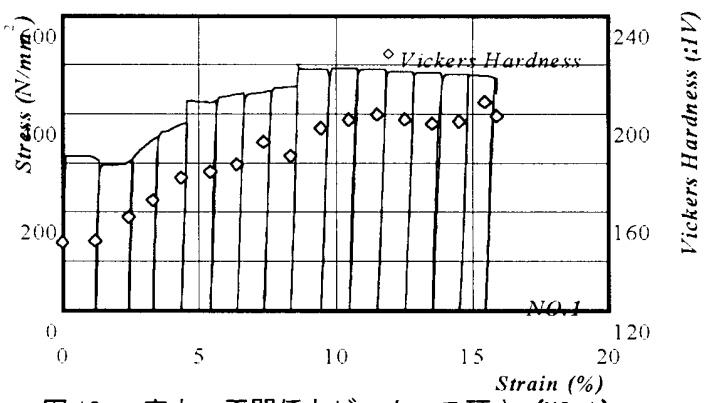

図 10 応カー歪関係とビッカース硬さ（N0.1）

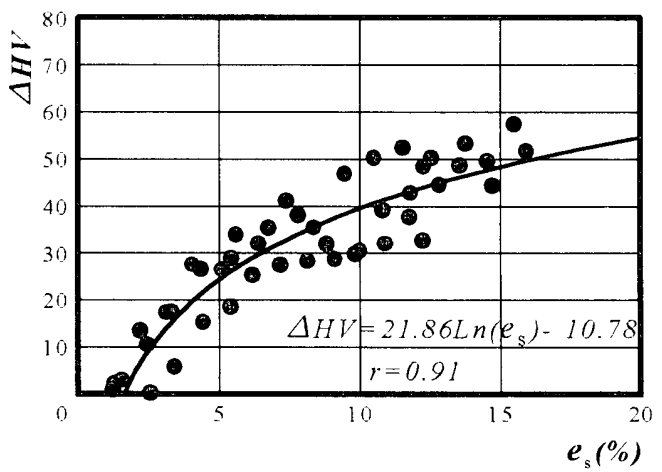

図 11 スケルトン歪とビッカース硬さ変化量の関係 
: 表 7 梁フランジが受けた塑性歪の推定結果

\begin{tabular}{|c|c|c|c|c|c|c|c|c|c|c|c|c|}
\hline \multirow{3}{*}{$\begin{array}{l}\text { 距離 } \\
(\mathrm{mm})\end{array}$} & \multicolumn{4}{|c|}{2 階床梁 } & \multicolumn{4}{|c|}{ 3階床梁 } & \multicolumn{4}{|c|}{4 階床梁 } \\
\hline & \multicolumn{2}{|c|}{ 上フランジ } & \multicolumn{2}{|c|}{ 下フランジ } & \multicolumn{2}{|c|}{ 上フランジ } & \multicolumn{2}{|c|}{ 下フランジ } & \multicolumn{2}{|c|}{ 上フランジ } & \multicolumn{2}{|c|}{ 下フランジ } \\
\hline & $\Delta H V$ & $e s(\%)$ & $\Delta H V$ & es $(\%)$ & $\triangle H V$ & $e s(\%)$ & $\triangle H V$ & $e s(\%)$ & $\triangle H V$ & $e s(\%)$ & $\Delta: H V$ & $e s(\%)$ \\
\hline 梁端 & 38 & 9 & 58 & 24 & 4.3 & 11 & 53 & 19 & 13 & 3 & 28 & 5 \\
\hline 40 & 26 & 50. & 54 & 20.1 & 31. & 6.2 & 48 & 14.7 & 10. & 2.3 & 25 & 5.0 \\
\hline 100 & 18 & 3.3 & 35 & 7.8 & 18 & 3.3 & 39 & 9.3 & 8 & 2.0 & 15 & 2.9 \\
\hline 160 & 14 & 27 & 27 & 5.1 & 12 & 2.4 & 34 & 7.4 & 7 & 1.9 & 9 & 2.1 \\
\hline 220 & 11 & 2.3 & 21 & 3.8 & 7 & 1.9 & 31 & 6.3 & 6 & 1.8 & 5 & 1.7 \\
\hline 280 & 8 & 2.1 & 16 & 3.0 & 4 & 1.6 & 28 & 5.5 & 6 & 1.8 & 2 & 1.5 \\
\hline 340 & 7 & 1.9 & 12 & 2.5 & 1 & 1.4 & 26 & 5.1 & 5 & 1.7 & 1 & 1.4 \\
\hline 452 & 4. & 1.7 & 7 & 1.9 & - & $=$ & 24 & 4.4 & 4 & 1.7 & - & - \\
\hline
\end{tabular}

$1 \%$ 塑性歪を与えるごとに除荷して、ビッカース硬さ試験を行な った。硬さの計測は引張り試験で最大応力を示すまで行なった。引 張り試験の載荷速度は $1 \mathrm{~mm} / \mathrm{min}$ である。硬さ試験は、ゲージ貼付 位置近傍の 5 点を打点し、その平均值を用いて評価した。

\section{2 試験結果}

試験結果を表 6 に示与。図 10 に応力一歪関係上硬さの関係の例 を示す。歪の上昇及び応力の上昇に伴って硬さが上昇している。

引張り試験で与えた歪は、繰返し載荷試験のスケルトン歪に対応 している。図 11 にスケルトン歪と硬さ变化量の関係を示す。これ によると、硬さ変化量とスケルトン歪の関係は非常によい相関関係 にあり、次式(3)によって表せるよいえる。

$$
\Delta H V=21.86 \operatorname{Ln}\left(e_{S}\right)-10.78
$$

$\Delta H V:$ ビッカース硬さ変化量 $(\mathrm{HV})$

$e_{s}$ : スケルトン歪 $(\%)$

\section{6. 地震による塑性歪の推定}

式(3)と図 7 を用いて、梁フランジのシャルピー衝撃試験片採取 位置及び引張り試験片採取位置でのスケルトン歪を求める。計算結 果を表 7 に示寺。

これによるよ、2 階床梁下フランジの梁端部近傍では約 $24 \% 、 3$ 階床梁下フランジー゙約 19\%、4 階床梁下フランジで注約 5\%のスタ ルトン歪を受けたことが推定できる。24\%の歪は、処女材の引張り 試験結果の一様伸びレほぼ同じ值であり、非常に大きな塑性変形を゙ 受けた後に脆性破壊したことが推定される。

また、ここで求めたスケルトン歪上脆性破面遷移温度変化量の関 係をブロットしたものが図 12 である。これによる上脆性破面遷移 温度とスケルトン歪の関係注次の近次式(4)で表せるこさがわかる。

$\Delta \operatorname{Trs}=17.09 \operatorname{Ln}\left(e_{s}\right)-1.71$

$\Delta T r s$ :脆性破面遷移温度変化量 $\left({ }^{\circ} \mathrm{C}\right)$

$e_{s}$ :推定スクルトン歪量 $(\%)$

7. まとめ

兵庫県南部地震によって被災し、柱梁接合部で脆性破壊なよ゙の被 害を受けた建築物の柱梁接合部近傍から材料試験片を採取して各 種材料試験を行ない、地震による入力之脆性破壊の発生要因、塑性 歪に上る材質変化について検討したところ、次のこ上が明らかにな oto

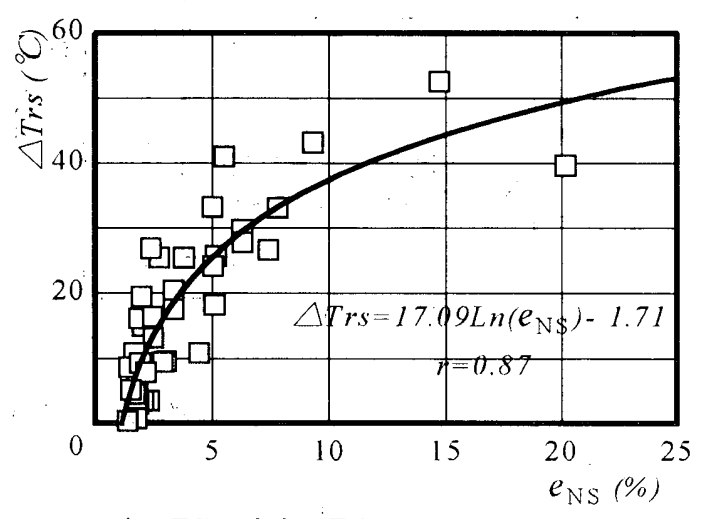

図 12 破面遷移温度变化量とスケルトン歪の関係 (SS41)

1. 梁フランジの脆性破壊は、梁ウェブスカラップ底の裏当て金 組立溶接部上の重畳部を起点としており、スカラップの存在よ、 裏当て金の連続組立て溶接が H 形鋼梁のフィレット部に重な っていたここが原因よなって発生したもの上思われる。

2. 脆性破壊が見られた $2 、 3$ 階梁下フランジでは、材質の変化が 著しく、梁端部に最も近い採取可能な位置（シャルビー衝揧試 験片は約 $40 \mathrm{~mm}$ 、引張試験片は約 $100 \mathrm{~mm}$ ）门試験片では、シャ ルビー遷移温度が 40 から $50^{\circ} \mathrm{C}$ 上昇し、降伏応力上引張り強さ はそれぞれ約 $100 \mathrm{~N} / \mathrm{mm}^{2} 、 40 \mathrm{~N} / \mathrm{mm}^{2}$ の上昇、一様伸びは約 $14 \%$ 低下、ビッカース硬さは約 $50 \mathrm{HV}$ 上昇しており、十分な塑性変 形の後に脆性破壊したものと思われる。

3. SS41 鋼のビッカース硬さ変化量し鋼材の歪履歷を表すスタル トン歪忙近似式(3)に、スケルトン歪上脆性破面遷移温度の関係 は近似式(4)によって表せる。

4. 梁端部の歪履歷を推測したところ、2 階床梁で $24 \% 、 3$ 階床梁 で 19\%、4 階床梁で 5\%程度のスタルトン歪を受けたもの上考 えられる。

5. 柱部材はほ上んど材質に変化は見られなかったことから、柱 は汪上儿ど塑性歪孛受けていない上考えられる。

6. 梁フランジの勒性は $0^{\circ} \mathrm{C}$ 吸収エネルギーがほぼ $100 \mathrm{~J}$ 在超えて 招り、十分な勒性を有していたとい方。 
《参考文献》

1) 加藤勉・森田耕次「極厚鋼部材の脆性破壊」日本建築学会論文報 告集 第 156 号 $\quad \mathrm{ppl} \sim 10 \quad 1969.2$

2）加藤勉・森田耕次・橋本健一「極厚鈰部材》脆性破壊（关の2）। 日本建築学侌論文報告集 第 176 号 pp11～16 1970.10

3) 藤本盛入・橋本篤秀・中込忠男・金鍾洛・松村弘道「柱法り溶接接 合部の破壊特性の検討（そ0１厚板鋼板を用い店柱はり溶接接合部 ○破壊に関卞る実験的研究）」 日本建築学会搆造系論文報告集 第 349 号 $\mathrm{pp} 81 \sim 90 \quad 1985.3$

4) 藤本盛久・橋本篤秀・中远忠男・金鍾洛・松村弘道「柱㳉り溶接接 合部の力学的性状扮上で破壊に及法吉影響について（その2 厚板銅 板を用い庆柱注り溶接接合部心破壊に関卞学実験的研究）」日本建 築学会構造系論文報告集 第 357 号 $\quad$ pp81 88 1985.11

5） 中远忠男・矢部喜堂・坂本真一「梁スカラップの有無が $\mathrm{H}$ 形断面柱に 溶接接合される $\mathrm{H}$ 形銅梁端部学的性状に及玨吉影響」日本建築 学会構造系論文報告集 第 432 号 pp.51 59 19922

6) 矢部喜堂・坂本真一・中込忠男「梁スカラップり有無方箱型断面柱に 溶接接合されるH形銅注り端部の力学的性状に及汪寸影響」日本建 築学会構造系論文報告集 第 440 号 pp.125 132 199210

7) Yositaka Yabe,Tadao Nakagomi,Shinichi Sakamoto Rationalization of Steel Structure Welding for Building in Japan-Mechanical Behaviors of Beam-toColumn Welded Joints without Beam Scallops -$\rfloor$ Document for IIW Annual Assembly 1990) in Montreal,Canada,July 1990,XV-728-90

8) 中込忠男・藤田哲也「角形銅管柱に通しダイアフラム形式で溶接接 合される在延H形銅梁端部门力学的性能(梁スカラップの有無お上ず 形状上目違いが破壊性状に及娍寸影響)」日本建築学会構造系論文報 告集 第 455号 pp.187〜196 19941

9) 中远忠男・藤田哲也・南圭祐・李建・村井正敏「柱梁溶接接合部に おけるノンスカラップ工法梁端ラ゙ィテールに関する実験的研究」 日本建筑学会構造系論文報告集 第 498 号 pp. 145 151 1997.8

10) 中込忠男 - 矢部喜堂・金本秀雄・横山重和・軽部正彦「銅構造溶

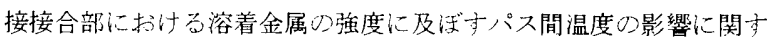
万検討」構造工学論文集 Vol.36B pp333～340 1990.3

11）藤本盛久・難波恒夫・中込忠男・佐々木聡「地震力を受け名単一

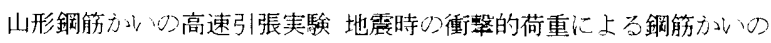
破断に関寸実娩的研究」 日本建筑学全構造系論文報告集 第 389 号 $\quad$ pp32 40 $\quad 1988.7$

12）中込忠男・土橋博明「高速載荷に上溶接丁継手の变形能力上破

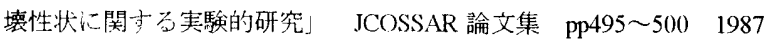

13) FUJMOTO Morihisa,NANBA Tsuneo,NAKAGOMI Tadao,SASAKI Satoshi ISTRENGTH AND DEFORMATION CAPACTTY OF STEEL BRACE UNDER HIGH-SPEED LOADNG」9WCEE PROCEEDINGS Vol. IV 1988. Tokyo-Kyoto,JAPAN

14) NAKAGOMI Tadao,TSUCHIHASHI Hiroaki 「FRACTURE AND DEFORMATION CAPACITY OF A WELDED T-SHAPE JOINT UNDER DYNAMIC LOADING $\rfloor$ 9WCEE PROCEEDINGS Vol.IV 1988.TokyoKyoto,JAPAN

15）中远忠男 - 山田丈富 -中野秀二 - 岡希光 - 的場耕 - 村井正敏「高 速載荷に上言柱梁溶接接合部门力学的性能に関子字実験的研究」 日本建築学会構造系論文報告集 第499 号 pp115 122 1997.9

16）中远忠男・見波進・新井聡・大野京子「柱梁接合部门脆性破壊に

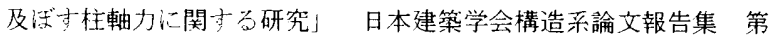
486 号 pp.125 pp. $132 \quad 1996.8$
17）中込忠男「建築鉄骨の現状とその要求性能」日本鉄鋼協会詇演 論文集 討 52 Vol.4 No.3 1991

18）藤本盛久・青榑文・中込忠男 - 寺田貞一・脇山広三「電炬広幅

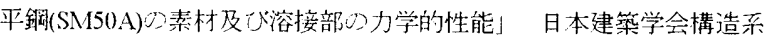
論文報告集 第 415 号 $\quad$ pp89 103 1990.9

19）青木博文・村思耕司「構造用銅材つ降伏点、引張強さお上ざ降伏 比に関寸る統計的調查」日本建築学会論文報告集 第 335 号 pp157 166 1984.1

20）青木博文・中远忠男 - 矢部喜堂 - 古藤凱生 - 山本美佐夫 他「熱 間矯正法に上光鋼材の勒性劣化に関卞方実騒的研究」日本建築学 会大会学術講演梗概集 東北 1991.9

21）青木博文・中込忠男 ·矢部喜堂・古藤凱生・中根一臣・新井聡「熱 間矯正法が柱梁溶接接合部の耐力、变形能力に及济す影響に関する 実騃的研究」構造工学論文集 Vol.39B (日本建築学会) 1993.3

22）藤本盛久・青木博文・中远忠男・西沢潡「電炍広幅平銅及び電炉

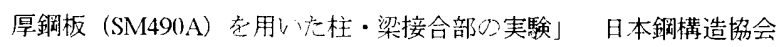
鎡構造論文集 Vol.1 NO.4 ppl27 142 1994.12

23）藤本盛久・青木博文・中込忠男・西沢淳「電炉広幅平銅及び電炉 厚鋼板（SM490A）在用w柱・梁接合部心破壊性状上素材特性心関 倸」日本銅構造協会銅構造論文集 Vol.1 NO.4 ppl43～157 1994.12

24）藤本盛久・青木博文・中远忠男・西沢㳯「電炉広幅平銅及び電炉 厚銅板 $(\mathrm{SM} 490 \mathrm{~A})$ 在用いた柱・梁接合部心塑性変形能力確保のた ○銅材以性能! 日本銅構造協会銅構造論文集 $\quad$ pp61 72 1995.8

25）藤本盛久・青木博文・中込忠男・西沢淳「電炉広幅平銅 $(S M 490$ A) を用いた柱梁接合部仕口ディテールの改良と塑性変形能力の向上」 日本鋼構造協会龬構造論文集 pp19～30 1996.9

26）中込忠男・青木博文「塑性歪を受计满造用銅材の力学的性能に 関古它験的研究」日本建築学会構造工学論文集 Vol.38 B 1992.3

27）中込忠男・山田丈富・日高新悟・大林郁良「䆆返し塑性歪を受ける

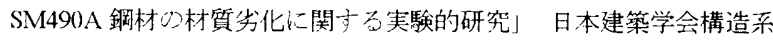
論文報告集 No.489 pp87〜94 1996.11

28）長谷川隆「1995 年兵庫県南部地震で梁端部方破断した鉄骨造建筑 物心弾塑性応答性状! 日本建築学会棈造采論文報告集 No.498 pp129 136 1997.8

29) 青木博文·鉿木勇「床スラブの影䇾を考虑した鋼構造骨組梁端 ひず双の举動」鋼構造年次論文報告集 第 4 巻 pp129１34 1996.11

(1997年10月10日原稿受理，1998年3月26日採用決管） 